\title{
Redaktørernes forord
}

Pierre Bourdieu og Axel Honneth hører i dag til nogle af de mest avancerede og systematiske sociologiske og socialfilosofiske skribenter. Bourdieus arbejde er i dag almenkendt på alle højere læreranstalter og Honneths arbejde synes, efter at han har fået oversat en række tekster til dansk, at have vundet terræn også i Danmark gennem de seneste år. De to forfatterskaber er interessante at placere side om side, da de dels deler en række emancipatoriske hensigter, dels repræsenterer vidt forskellige sociologiske og socialfilosofiske traditioner. Men det er ikke kun deres væsensforskellige veje, som leder dem frem til den samme emancipatoriske bestræbelse, som er interessante, men i høj grad også deres vidt forskellige institutionelle forankring. For på samme måde som Bourdieu læner sig op af sit franske ophav, er Honneth rodfæstet i den tyske tradition; hvor Bourdieu i dag fremstår som grundlæggeren af sin egen skole, så betragtes Honneth som den vigtigste repræsentant for tredje generation af Frankfurterskolen. Trods deres vidt forskellige skolastiske traditioner, så har de begge arbejdet intenst hen over det tysk-franske grænseland. Bourdieu har oversat nogle af de mest centrale værker af Max Weber, og Honneth var den første som introducerede Michel Foucault for Frankfurterskolen, ligesom han var det formidlende led ved første møde mellem Jürgen Habermas og Jacques Derrida. På samme måde som de hver især har introduceret centrale forfattere hen over det tysk-franske grænseland, så indgik dette temanummers centrale tekst mellem Bourdieu og Honneth også i Ästhetik und Kommunikation (1986b) om Bourdieu, blandt andet foranlediget af Honneth.

Temanummeret byder på tre tekster af Pierre Bourdieu og et essay af Axel Honneth om Bourdieu, samt Honneth's nekrolog over Bourdieu. Samtalen mellem Bourdieu, Honneth, Kocyba og Schwibs er temanumrets centrale tekst. Teksterne giver tilsammen et usædvanligt indblik i de to forfatteres forskelligheder og ligheder, ligesom de alle bidrager til at skærpe blikket for de to forfatteres modstridende positioner. Det er især samtalen mellem de to, som på slående vis illustrerer begges intellekt og teoretiske standpunkt: Honneth bliver ubønhørligt ved med at forhøre sig ved hjælp af en række skarpe omformuleringer, og Bourdieu svarer hver gang forskelligt uden at give efter i synspunkter og holdninger.

De oversatte tekster er fra midt 80'erne, men den teoretiske problematik, som er til diskussion i teksterne, er ligeså aktuel i dag. Den centrale problematik for nærværende temanummer er nemlig principperne for videnskabelig kritik - ikke mindst inden for sociologien. Disse tekster fra 1980'erne giver yderligere et sjæl- 
dent indblik i mødet mellem to af Europas største tænkere. Et møde som ingen sociolog bør være foruden.

Vi vil gerne takke Axel Honneth og Monica Denz (Honneths sekretær) for hjælp ved fremskaffelse af originale manuskripter, rettigheder og billedmateriale. En stor tak skal også rettes til Jerome Bourdieu for tilladelse til at oversætte og publicere Bourdieu-teksterne. Under tilblivelsen af dette temanummer ytrede Honneth, at han arbejdede med endnu et essay om Bourdieu, men på grund af et uforudset arbejdspres i forbindelse med afholdelsen af Tanner-forelæsninger på UCLA, Berkeley blev han desværre forhindret i at færdiggøre essayet. Vi vil også gerne rette en speciel tak til Jonas Jacobsen, som har oversat Honneths tekster.

I tillæg til de oversatte artikler af og om Pierre Bourdieu indeholder numret et review essay af Anders Mathiesen om Bourdieus videnskabsteori med baggrund i udgivelsen af Bourdieus forelæsninger på Collège de France i 2000-2001 samt tre anmeldelser af publikationer om og af Bourdieu samt diskussionen mellem Nancy Fraser og Axel Honneth.

Redaktionen vil også benytte lejligheden til at ønske vore læsere et rigtig godt nytår med de bedste håb om et godt og sociologisk inspirerende år 2006.

Thomas P. Boje, Anders Mathiesen og Rasmus Willig 